\title{
EFEK PENAMBAHAN KITOSAN TERHADAP PERUBAHAN JUMLAH TOTAL HEMOSIT DAN DAYA TAHAN TERHADAP STRES SALINITAS PADA UDANG VANAME (Litopenaeus vannamei)
}

\section{Effect of Addition Chitosan to Total Haemocyte Count Changes and Salinity Stress Tolerance of White Shrimp (Litopenaeus Vannamei)}

\author{
Okky Hermawan $^{1}$, Woro Hastuti Satyantini ${ }^{2}$ dan Prayogo ${ }^{2}$. \\ ${ }^{1}$ Program Studi Budidaya Perairan, Fakultas Perikanan dan Kelautan, Universitas Airlangga, Surabaya \\ ${ }^{2}$ Departemen Manajemen Kesehatan Ikan dan Budidaya Perairan, Fakultas Perikanan dan Kelautan, Universitas \\ Airlangga, Surabaya \\ *okky-h-10@fpk.unair.ac.id
}

\begin{abstract}
Abstrak
Udang vaname (Litopenaeus vannamei) merupakan suatu komoditas unggulan industri perikanan Indonesia. Pada budidaya udang vaname, muncul beberapa kendala, yaitu adanya serangan penyakit yang disebabkan oleh virus dan bakteri. Hal tersebut dapat diatasi dengan pemberian imunostimulan untuk pencegahan penyakit melalui peningkatan sistem imun udang. Kitosan adalah salah satu bahan yang dapat digunakan sebagai imunostimulan. Kitosan dapat meningkatkan sistem imun. Stres merupakan respon fisiologis yang terjadi saat hewan berusaha mempertahankan kondisi tubuhnya dari perubahan lingkungan. Faktor lingkungan seperti suhu, oksigen terlarut dan salinitas dapat menyebabkan terjadinya perubahan jumlah total hemosit. Jumlah total hemosit dapat digunakan untuk mengetahui status kesehatan udang.

Penelitian ini bertujuan untuk mengetahui efek penambahan kitosan pada pakan terhadap perubahan jumlah total hemosit dan daya tahan terhadap stres salinitas pada udang vaname (Litopenaeus vannamei). Metode penelitian yang digunakan adalah eksperimental menggunakan Rancangan Acak Lengkap (RAL) dengan empat perlakuan serta empat ulangan. Perlakuan yang digunakan adalah penambahan kitosan sebesar 0 $\mathrm{mg} / \mathrm{kg}$ pakan (A1), $250 \mathrm{mg} / \mathrm{kg}$ pakan (A2), $500 \mathrm{mg} / \mathrm{kg}$ pakan (A3) dan $1000 \mathrm{mg} / \mathrm{kg}$ pakan (A4). Parameter yang diamati adalah jumlah total hemosit selama 14 hari pemeliharaan, 24 jam dan 48 jam setelah uji stres salinitas, kelangsungan hidup saat uji stres salinitas dan kualitas air. Data dianalisis menggunakan Analisis Varian (Anova) dan dilanjutkan dengan Uji Jarak Berganda Duncan.

Hasil penelitian yang dilakukan menunjukkan bahwa penambahan kitosan pada pakan selama 14 hari pemeliharaan dan selama 24 jam setelah uji stres salinitas memberikan pengaruh yang berbeda nyata $(\mathrm{p}<0,05)$ terhadap jumlah total hemosit udang vaname dengan jumlah total hemosit tertinggi diperoleh pada perlakuan A2 (250 mg kitosan/kg pakan). Empat puluh delapan jam setelah uji stres salinitas tidak memberikan pengaruh yang nyata terhadap jumlah total hemosit udang vaname dan kelangsungan hidup udang vaname.
\end{abstract}

Kata kunci : Udang Vaname, Kitosan, Hemosit, Uji Stres Salinitas

\begin{abstract}
White shrimp is a one of leading commodity fisheries industry in Indonesia. There are some constraints in its culture, caused by viruses and bacteria. But it can be solved by increasing the immune system of shrimp. Chitosan is one of the materials that can be used as an immunostimulant. Chitosan can stimulate the immune system. Stress is a physiological response that occurs when the animals try to maintain condition of environmental changed. The environmental factor such as temperature, dissolved oxygen and salinity may change total haemocyte count. Total haemocyte count can be used to know the health status of the shrimp.

The purpose of research to determine the effect of addition chitosan on feed to total haemocyte count changes and salinity stress tolerance. The method of research used experimentaly method by using completely random design (RAL) with four treatments and four repetitions. Treatments which were used addition chitosan 0 $\mathrm{mg} / \mathrm{kg} \operatorname{diet}(\mathrm{A} 1$ ), $250 \mathrm{mg} / \mathrm{kg}$ diet (A2), $500 \mathrm{mg} / \mathrm{kg} \operatorname{diet}(\mathrm{A} 3)$ and $1000 \mathrm{mg} / \mathrm{kg}$ diet (A4). The main parameter which was observed were total haemocyte count changes for 14 days, 24 hours and 48 hours after salinity stress test, survival rate at salinity stress test and water quality. The results were analyzed by Analysis of Varian (Anova) continued by Duncan's Multiple Range Test.

The result showed that chitosan addition in feed for 14 days and 24 hours after salinity stress test, gave the significantly different $(\mathrm{P}<0.05)$ to total haemocyte count of white shrimp with the highest of total haemocyte
\end{abstract}


count obtained in treatment of A2. Fourty eight hours after salinity stress test did not give the significant different to total haemocyte count and survival rate of white shrimp.

Key word: Vannamei Shrimp, Chitosan, Haemocyte, Salinity Stress Test

\section{PENDAHULUAN}

Udang vaname (Litopenaeus vannamei) merupakan suatu komoditas unggulan industri perikanan Indonesia. Muncul beberapa kendala pada budidaya udang vaname yaitu adanya serangan penyakit yang disebabkan oleh virus dan bakteri (Sukenda dkk., 2007). Salah satu upaya untuk pencegahan penyakit adalah dengan meningkatkan sistem imun udang dengan cara pemberian imunostimulan (Pujiati dkk., 2013).

Salah satu bahan imunostimulan adalah kitosan (Sukenda dkk., 2007). Suptijah (2006) menyatakan, bahwa kitosan dapat merangsang sistem imun dan bersifat antibakteri. Meshkini et al. (2012) melaporkan bahwa penggunaan kitosan pada pakan sebagai imunostimulan mampu meningkatkan total sel darah putih pada ikan rainbow trout (Onocorhynchus mykiss).

Subyakto (2000) menyatakan, bahwa stres merupakan respon fisiologis yang terjadi saat hewan berusaha mempertahankan kondisi tubuhnya dari kondisi lingkungan, contohnya adalah salinitas. Salinitas dapat mempengaruhi perubahan jumlah total hemosit. Hal ini sesuai dengan pernyataan Van de Braak et al. (2002), bahwa faktor lingkungan seperti suhu, Salinitas dan oksigen terlarut dapat menyebabkan perubahan jumlah total hemosit pada Crassostrea virginica di alam. Manoppo (2011) dan Putri dkk. (2013) menyatakan bahwa jumlah total hemosit dapat digunakan untuk memantau status kesehatan udang karena hemosit krustasea memainkan peranan penting dalam sistem pertahanan tubuh udang terhadap patogen seperti virus, bakteri, fungi, protozoa dan metazoa. Jumlah total hemosit juga dapat bervariasi berdasarkan beberapa faktor, salah satunya disebabkan oleh stres lingkungan.
Beberapa keunggulan yang dimiliki oleh kitosan salah satunya yaitu dapat digunakan sebagai bahan imunostimulan, maka perlu dilakukan penelitian tentang pengaruh penambahan kitosan terhadap perubahan jumlah total hemosit dan daya tahan terhadap stres salinitas pada udang vaname (L. vannamei).

\section{METODOLOGI}

Waktu dan Tempat

Penelitian ini dilaksanakan pada bulan Agustus-September 2014 di Laboratorium Pendidikan Fakultas Perikanan dan Kelautan Universitas Airlangga Surabaya.

\section{Materi Penelitian}

Peralatan Penelitian

Alat yang digunakan terdiri atas akuarium berukuran $(50 \times 30 \times 30) \mathrm{cm}^{3}$, aerator, selang aerasi, timbangan digital, gelas ukur, kompor listrik, Beaker glass, tabung berskala, alumunium foil, refraktometer, pH meter, Dissolve Oxygen (DO) kit, termometer, gunting, sterofoam, mikroskop, syringe, ammonia test kit, pipet, microtube dan haemositometer.

\section{Bahan Penelitian}

Bahan yang digunakan dalam penelitian ini adalah udang vaname stadia dewasa dengan panjang 10-11 cm, air tawar, air laut, kitosan dari limbah cangkang kepiting bakau, pakan udang (pelet), akuades, $\mathrm{HCl} 1 \mathrm{~N}, \mathrm{NaOH} 3,5 \%, \mathrm{NaOH} 50$ $\%$, alkohol $70 \%$, antikoagulan $(30 \mathrm{mM}$ trisodium citrate, $0.34 \mathrm{M}$ sodium chloride, $10 \mathrm{mM}$ EDTA, $\mathrm{pH}$ 7.5) dan asam asetat 1 $\%$.

\section{Metode Penelitian}

Rancangan penelitian menggunakan metode eksperimental dengan Rancangan Acak Lengkap (RAL) satu faktor 
dengan 4 taraf perlakuan, untuk memperkecil kekeliruan maka setiap perlakuan diberi pengulangan sebanyak 4 kali sehingga diperoleh 16 unit percobaan.

\section{Prosedur Kerja \\ Persiapan Penelitian}

Peralatan yang digunakan dicuci sampai bersih kemudian dibilas dengan air tawar. Peralatan yang sudah bersih disterilkan dengan larutan khlorin 150 ppm. Kemudian, peralatan dikeringkan di bawah sinar matahari.

\section{Pembuatan Kitosan}

Kitosan diperoleh melalui turunan kitin yang berasal dari limbah cangkang kepiting bakau. Masduki (1996) dalam Djamaludin (2009) menerangkan, pembuatan kitosan dibagi menjadi tiga tahap. Tahap pertama disebut demineralisasi, yaitu perendaman kulit kepiting dalam larutan $\mathrm{HCl} 1 \mathrm{~N}$ dengan perbandingan 1:7 selama 8 jam. Tahap kedua adalah deproteinasi, yaitu perendaman hasil demineralisasi dalam $\mathrm{NaOH} 3,5 \%$ selama 1 jam pada suhu $90^{\circ} \mathrm{C}$. Tahap terakhir adalah deasetilasi, yaitu perendaman hasil deproteinasi dalam $\mathrm{NaOH} 50 \%$ pada suhu $100^{\circ} \mathrm{C}$. Hasil kitosan yang sudah jadi tersebut dalam bentuk bubuk.

\section{Persiapan Hewan Uji}

Hewan uji yang digunakan pada penelitian adalah udang vaname yang berasal dari Balai Pengembangan Budidaya Air Payau (BPBAP) Situbondo. Udang vaname stadia dewasa terpilih tersebut memiliki panjang $10-11 \mathrm{~cm}$. Sebelum diberi perlakuan, udang vaname diaklimatisasi selama satu minggu pada akuarium dengan kepadatan 10 ekor setiap akuarium dan diberi aerasi pada kondisi laboratorium. Kualitas air dijaga agar tetap pada kisaran optimal untuk pemeliharaan udang, yaitu suhu air media berkisar antara 27,5-29 ${ }^{\circ} \mathrm{C}$; $\mathrm{pH}$ 7,2-7,4; kandungan oksigen terlarut (DO) 4,00-8,00 mg/L, salinitas sebesar 32-35 ppt, dan ammonia sebesar
0,03-0,23 mg/L (Eloovara, 2001; KPPKP, 2012; Putri dkk., 2013).

\section{Persiapan Pakan}

Menurut Hafiluddin dan Triajie (2011) yang telah dimodifikasi, prosedur pembuatan larutan kitosan $250 \mathrm{mg} / \mathrm{kg}$ pakan adalah serpihan kitosan ditimbang sebanyak $250 \mathrm{mg}$, kemudian melarutkannya ke dalam asam asetat $1 \%$ sebanyak 10 ml dan diaduk sampai larut kemudian dimasukkan ke dalam gelas ukur, setelah itu dimasukkan akuades ke dalam gelas ukur hingga volumenya mencapai $300 \mathrm{ml}$ untuk memudahkan pencampuran ke dalam pakan. Untuk pembuatan larutan kitosan 500 ppm dan 1000 ppm prosedurnya sama dengan pembuatan larutan kitosan $250 \mathrm{ppm}$.

Pakan yang digunakan dalam penelitian ini adalah berupa pakan udang vaname komersial (pelet) dengan kandungan protein $36 \%$, serat kasar $4 \%$, lemak $5 \%$, kadar air $12 \%$ dan kadar abu $15 \%$. Larutan kitosan sesuai dosis perlakuan (250 mg, $500 \mathrm{mg}$ dan $1000 \mathrm{mg}$ ) kemudian dicampurkan ke dalam $1 \mathrm{~kg}$ pakan komersial untuk masing-masing perlakuan. Setelah tercampur antara pakan komersial dengan larutan kitosan, campuran pakan udang tersebut di-repelet atau dicetak ulang sehingga bentuk dan ukurannya kembali ke ukuran awal.

Pakan udang vaname diberikan sebanyak $3 \%$ dari total berat tubuh. Frekuensi pemberian pakan dilakukan tiga kali sehari, yaitu pukul 09.00 WIB, 13.00 WIB dan 17.00 WIB (Putri dkk., 2013).

\section{Uji Stres Salinitas}

Uji stres salinitas adalah suatu uji perlakuan salinitas yang dapat dinaikkan atau diturunkan dengan tujuan untuk mengetahui tingkat ketahanan tubuh pada udang vaname. Uji stres dilakukan dengan cara memindahkan hewan uji dari akuarium pemeliharaan dengan salinitas $30 \mathrm{ppt}$ ke dalam akuarium pemeliharaan dengan salinitas 20 ppt. Menurut Taqwa dkk. (2012), tingkat kematian rentan terjadi 
akibat adanya perubahan salinitas yang diduga disebabkan oleh perubahan osmotik yang terlalu besar. Menurut Meshkini et al. (2012), uji stres salinitas dilakukan selama 48 jam. Pengamatan jumlah total hemosit dilakukan pada 24 jam dan 48 jam setelah uji stres salinitas. Pengamatan kelangsungan hidup hewan uji dilakukan setiap 6 jam sekali.

\section{Parameter Pengamatan}

Parameter utama pada penelitian ini adalah jumlah total hemosit atau Total Haemocyte Count (THC) dan kelangsungan hidup saat uji stres salinitas. Parameter pendukung pada penelitian ini meliputi: suhu, $\mathrm{pH}$, salinitas, (DO), kadar ammonia dan pengamatan fisiologis pada udang vaname saat uji stres salinitas.

\section{Analisis Data}

Analisis statistik menggunakan Analisis Varian (Anova) untuk mengetahui pengaruh pemberian kitosan dengan dosis yang berbeda terhadap perubahan jumlah total hemosit dan kelangsungan hidup udang vaname. Untuk mengetahui letak perbedaan pengaruh antar perlakuan dilanjutkan dengan Uji Jarak Berganda Duncan (Duncan's Multiple Range Test) (Kusriningrum, 2009).

\section{HASIL DAN PEMBAHASAN Hasil}

Data jumlah total hemosit pada hari ke-0 (sebelum perlakuan), selama 14 hari pemeliharaan yang diberi kitosan dengan dosis yang berbeda, 24 jam dan 48 jam setelah uji stres salinitas pada udang vaname terdapat pada Tabel 1.

Tabel 1. Jumlah Total Hemosit Udang Vaname (L. vannamei)

\begin{tabular}{|c|c|c|c|c|}
\hline \multirow{2}{*}{ Perlakuan } & \multicolumn{4}{|c|}{ Rata-rata $(\bar{x})$ jumlah total hemosit udang vaname } \\
& (x10 & \multicolumn{3}{c|}{ sel/ml $) \pm$ SD } \\
\cline { 2 - 5 } & Hari ke-0 & Hari ke-14 & $\begin{array}{c}24 \text { jam setelah } \\
\text { uji stres salinitas }\end{array}$ & $\begin{array}{c}48 \text { jam setelah } \\
\text { uji stres salinitas }\end{array}$ \\
\hline A1 & 20,9 & $25,95^{\mathrm{b}} \pm 3,61$ & $32,09^{\mathrm{c}} \pm 3,67$ & $39,78^{\mathrm{a}} \pm 3,63$ \\
A2 & 20,9 & $36,58^{\mathrm{a}} \pm 8,19$ & $51,15^{\mathrm{a}} \pm 4,30$ & $31,43^{\mathrm{a}} \pm 4,99$ \\
A3 & 20,9 & $21,54^{\mathrm{bc}} \pm 0,62$ & $28,80^{\mathrm{c}} \pm 6,33$ & $37,36^{\mathrm{a}} \pm 2,96$ \\
A4 & 20,9 & $23,61^{\mathrm{bc}} \pm 0,84$ & $39,45^{\mathrm{b}} \pm 1,39$ & $34,79^{\mathrm{a}} \pm 2,25$ \\
\hline
\end{tabular}

Berdasarkan hasil sidik ragam diketahui bahwa perlakuan pemberian kitosan dengan dosis yang berbeda menunjukkan hasil perbedaan yang nyata $(p<0,05)$ terhadap jumlah total hemosit selama 14 hari pemeliharaan udang vaname. Berdasarkan hasil Uji Jarak Berganda Duncan, maka diketahui bahwa jumlah total hemosit tertinggi adalah A2 $\left(36,58 \times 10^{6} \mathrm{sel} / \mathrm{ml}\right)$. Jumlah total hemosit terendah adalah A3 $\left(21,54 \times 10^{6} \mathrm{sel} / \mathrm{ml}\right)$.

Uji stres salinitas pada udang vaname menunjukkan hasil perbedaan yang nyata $(\mathrm{p}<0,05)$ terhadap jumlah total hemosit selama 24 jam setelah uji stres Salinitas. Berdasarkan hasil Uji Jarak Berganda Duncan, maka diketahui bahwa jumlah total hemosit tertinggi $(\mathrm{p}<0,05)$ adalah A2 $\left(51,15 \times 10^{6} \mathrm{sel} / \mathrm{ml}\right)$. Jumlah total hemosit terendah adalah A3 $(28,80$ $\left.\mathrm{x} 10^{6} \mathrm{sel} / \mathrm{ml}\right)$.

Pemberian kitosan pada pakan menunjukkan hasil tidak berbeda nyata ( $\mathrm{p}$ $<0,05)$ terhadap jumlah total hemosit selama 48 jam setelah uji stres salinitas pada udang vaname. Pada perlakuan A2 terjadi penurunan jumlah total hemosit, sedangkan pada perlakuan A1 masih terjadi peningkatan jumlah total hemosit pada udang vaname.

Data tingkat kelangsungan hidup udang vaname selama 14 hari pemeliharaan, 24 jam dan 48 jam saat uji stres salinitas terdapat pada Tabel 2 . 
Tabel 2. Tingkat Kelangsungan Hidup Udang Vaname (L. vannamei)

\begin{tabular}{|c|c|c|c|c|}
\hline \multirow{2}{*}{ Perlakuan } & \multirow{2}{*}{$\begin{array}{c}14 \text { hari } \\
\text { pemeliharaan } \\
(\%)\end{array}$} & \multicolumn{2}{|c|}{ Uji stres salinitas } & \multirow{2}{*}{ Rata-rata $(\bar{x}) \pm \mathrm{SD}$} \\
\hline & & 24 jam $(\%)$ & 48 jam $(\%)$ & \\
\hline A1 & 100 & 100 & 96,88 & $96,88^{a} \pm 0,33$ \\
\hline $\mathrm{A} 2$ & 100 & 100 & 96,88 & $96,88^{\mathrm{a}} \pm 0,33$ \\
\hline A3 & 100 & 100 & 94,44 & $94,44^{\mathrm{a}} \pm 0,59$ \\
\hline A4 & 100 & 100 & 96,88 & $96,88^{\mathrm{a}} \pm 0,33$ \\
\hline
\end{tabular}

Berdasarkan hasil sidik ragam diketahui bahwa uji stres salinitas menunjukkan tidak berbeda nyata $(\mathrm{p}>0,05)$ terhadap tingkat kelangsungan hidup udang vaname.

Respon fisiologi udang vaname selama 48 jam uji stres salinitas menunjukkan bahwa udang vaname pada perlakuan A2 $(250 \mathrm{mg} / \mathrm{kg}$ pakan $)$ telah berenang secara normal dan merespon pakan yang diberikan pada 12 jam setelah uji stres salinitas. Sementara udang vaname pada perlakuan A1 (kontrol) baru menunjukkan berenang secara normal dan merespon pakan pada 24 jam setelah uji stres salinitas.

\section{Pembahasan}

Penggunaan beberapa imunostimulan terbukti dapat meningkatkan respon imun pada ikan (Meskini et al., 2012). Peningkatan jumlah total hemosit tertinggi terjadi pada perlakuan A2 $(250 \mathrm{mg} / \mathrm{kg}$ pakan) dibandingkan perlakuan lainnya selama 14 hari pemeliharaan. Hal tersebut memperlihatkan bahwa pada perlakuan A2 dapat meningkatkan jumlah total hemosit pada udang vaname dibandingkan dengan perlakuan A1 (kontrol). Hal ini diduga karena kitosan yang komponen utamanya glukosamin mirip dengan lipopolisakarida dapat merangsang organ limfoid yang merupakan organ hematopoetik pada udang untuk memproduksi hemosit. Kondisi ini sesuai dengan hasil penelitian Salfira (1998) tentang pengaruh pemberian lipopolisakarida terhadap sistem kekebalan udang windu, yang menyatakan bahwa lipopolisakarida dapat meningkatkan jumlah total hemosit.
Hemosit disintesis oleh jaringan hematopoietik yang merupakan sepasang epigastric nodule. Produksi tersebut dilakukan untuk mencapai keadaan homeostatis pasca introduksi imunostimulan. Jaringan tersebut terletak tepat di bagian dorsal pada lambung bagian depan (anterior stomach), yaitu tempat sintesa hemocyanin. Bila imunostimulan dapat meningkatkan hemocyanin, maka secara langsung akan terjadi pula peningkatan hemosit (Ekawati dkk., 2012).

Jumlah total hemosit selama 24 jam setelah uji stres salinitas pada udang vaname tertinggi dicapai pada perlakuan A2 $\left(51,15 \times 10^{6} \mathrm{sel} / \mathrm{ml}\right)$. Pada uji stres salinitas, semua perlakuan mengalami peningkatan jumlah total hemosit. Tayibu (2012) menyatakan bahwa, peningkatan jumlah total hemosit tersebut diakibatkan oleh kontraksi jantung yang meningkat sebagai upaya homeostatis yang dikembangkan karena keadaan lingkungan yang berubah.

Pada saat 48 jam setelah uji stres salinitas, pada perlakuan A2 $\left(31,43 \times 10^{6}\right.$ $\mathrm{sel} / \mathrm{ml}$ ) mengalami penurunan jumlah total hemosit yang signifikan, sementara pada perlakuan A1 $\left(39,78 \times 10^{6} \mathrm{sel} / \mathrm{ml}\right)$ justru mengalami peningkatan. Hal ini menunjukkan udang vaname pada perlakuan A2 sudah berada dalam keadaan homeostasi karena jumlah total hemosit berangsur normal sementara pada perlakuan A1 masih mengalami stres karena masih belum mencapai keadaan homeostasi. Hal ini ditunjukkan dengan jumlah total hemosit pada perlakuan A1 yang masih meningkat.

Pada penelitian ini, dosis optimum pemberian kitosan melalui pakan pada udang vaname adalah sebesar $250 \mathrm{mg} / \mathrm{kg}$

Diterima/submitted:21 November 2015 Disetujui/accepted:11 Juli 2016 
pakan. Pada perlakuan A3 dan A4 juga dapat memberikan pengaruh, namun demikian ketika pemberian dosis itu melebihi batas kemampuan tubuh justru akan berdampak negatif pada udang. Hal ini sesuai dengan pendapat Ekawati dkk. (2012) yang mengatakan bahwa ketika pemberian pakan yang mengandung $C$. ceratosporum (salah satu bahan imunostimulan) melebihi batas kemampuan tubuh untuk meresponnya justru dapat menurunkan sistem kekebalan tubuh udang.

Stres adalah suatu keadaan dimana keseimbangan atau homoestasis yang normal pada tubuh udang terganggu atau terancam oleh faktor eksternal atau faktor lingkungan. Stres diawali dari perubahan fisiologi dan diekspresikan dalam respon perilaku yang bertujuan untuk membangun kembali keseimbangan atau kenyamanan dengan melalui memaksimalkan fungsi respirasi dan osmoregulasi. Hal ini dapat merugikan apabila terjadi secara kronis dan berkepanjangan (Wolffrom, 2004 dalam Tayibu, 2012). Osmoregulasi adalah pengaturan tekanan osmotik cairan tubuh yang layak bagi kehidupan ikan sehingga proses-proses fisiologis tubuhnya berjalan normal (Rahardjo, 1980 dalam Taqwa, 2008). Kaligis (2010) menyatakan, bahwa perubahan salinitas dapat menyebabkan udang mudah stres dan kurang nafsu makan.

Berdasarkan hasil sidik ragam tingkat kelangsungan hidup selama 48 jam setelah uji stres salinitas menunjukkan hasil tidak berbeda nyata. Hal ini dikarenakan saat uji stres salinitas, terjadi kematian pada udang vaname di setiap perlakuan. Kematian ini diduga udang vaname mengalami stres yang berkepanjangan akibat perubahan salinitas.

Stres dapat membuat udang menjadi lemah. Hal ini dikarenakan dalam keadaan stres, udang akan terlihat kurang respon terhadap pakan yang diberikan. Jika hal tersebut berlanjut secara berkepanjangan, udang akan mudah terserang penyakit apabila ada penyakit atau patogen asing yang menyerang. Hal ini sesuai dengan pendapat Tidwell (1998) dalam Evan (2009) yang menyatakan, bahwa munculnya penyakit merupakan akibat adanya interaksi antara agen penyebab penyakit, inang dan lingkungan. Dalam hal ini, lingkungan dapat menjadi stresor (penyebab munculnya penyakit), karena pada saat lingkungan memburuk, seperti adanya fluktuasi kualitas air secara ekstrim, udang mudah stres dan akibatnya rentan terhadap penyakit, serta dapat mengakibatkan kematian atau penurunan sintasan.

Lebih lanjut, Tayibu (2012) menyatakan, bahwa udang vaname yang stres terlihat dari kurang respon terhadap pakan yang diberikan dan cenderung diam di sudut akuarium. Dalam penelitian ini, pada rentang waktu 12 jam uji stres salinitas, rata-rata udang pada perlakuan A1 masih belum merespon pakan yang diberikan dan baru mulai merespon pakan yang diberikan pada rentang waktu 24 jam uji stres salinitas, sementara udang pada perlakuan A2 sudah mulai merespon pakan yang diberikan pada rentang waktu $12 \mathrm{jam}$. Hal ini mengindikasikan bahwa udang pada perlakuan A1 masih berada dalam fase stres sehingga udang tersebut kurang respon terhadap pakan yang diberikan, sementara udang pada perlakuan A2 sudah dalam keadaan homeostasi sehingga udang sudah dapat merespon pakan yang diberikan.

Kualitas air meliputi salinitas, suhu, pH, DO dan amoniak. Salinitas selama 14 hari pemeliharaan adalah $30 \mathrm{ppt}$ sementara saat uji stres diturunkan hingga mencapai 20 ppt. Suhu pada pagi hari berkisar $27-28$ ${ }^{\circ} \mathrm{C}$ dan pada sore hari yang berkisar 28-29 ${ }^{\circ} \mathrm{C}$. Hasil pengukuran $\mathrm{pH}$ selama penelitian berlangsung berkisar 7,2-7,4. Oksigen terlarut selama penelitian adalah 4,0-6,0 mg/l. Amoniak selama penelitian adalah berkisar 0,05-0,1 mg/l. Kualitas air selama penelitian sesuai dengan pendapat dari Eloovara (2001) bahwa suhu optimal untuk udang vaname berkisar $27,5-29{ }^{\circ} \mathrm{C}$, Putri dkk. (2013) bahwa $\mathrm{pH}$ optimal untuk udang vaname berkisar 7,2-7,4, nilai amoniak udang vaname sebesar $0,03-0,23 \mathrm{mg} / \mathrm{l}$ dan 
KPPKP (2011) bahwa kelarutan oksigen optimal pada udang vaname berkisar 4,0$8,0 \mathrm{mg} / \mathrm{l}$.

\section{KESIMPULAN DAN SARAN Kesimpulan}

Penambahan kitosan pada pakan selama 14 hari pemeliharaan dan 24 jam setelah uji stres salinitas memberikan pengaruh terhadap jumlah total hemosit udang vaname (L. vannamei). Jumlah total hemosit tertinggi diperoleh dengan penambahan kitosan $250 \mathrm{mg} / \mathrm{kg}$ pakan. Penambahan kitosan pada pakan tidak memberikan pengaruh terhadap jumlah total hemosit 48 jam setelah uji stres salinitas dan kelangsungan hidup udang vaname setelah uji stres salinitas.

\section{Saran}

Berdasarkan hasil penelitian, maka disarankan untuk menambahkan kitosan pada pakan komersial dengan dosis 250 $\mathrm{mg} / \mathrm{kg}$ pakan untuk meningkatkan jumlah total hemosit dan daya tahan terhadap stres salinitas pada udang vaname $(L$. vannamei).

\section{DAFTAR PUSTAKA}

Djamaludin, A. M. 2009. Pemanfaatan Khitosan Dari Limbah Krustasea Untuk Penyembuhan Luka Pada Mencit (Mus muscullus albinus). Skripsi. Fakultas Matematika dan Ilmu Pengetahuan Alam. Institut Pertanian Bogor. Bogor. 41 hal.

Ekawati, A. W., H. Nursyam, E. Widjayanto dan Marsoedi. 2012. Diatome Chaetoceros ceratosporum Dalam Formulasi Pakan Meningkatkan Respon Imun Seluler Udang Windu (Penaeus monodon). Jurnal Exp. Science, II (1): 20-28.

Eloovara, A. K. 2001. Shrimp Farming Manual: Practicial Technology For Intensive Shrimp Production. United States of America. Page 1-3.

Evan, Y. 2009. Uji Ketahanan Beberapa Strain Larva Udang Galah (Macrobrachium rosenbergii de Man)
Terhadap Bakteri Vibrio harveyi. Skripsi. Institut Pertanian Bogor. Bogor. 51 hal.

Halifuddin dan H. Triadjie. 2011. Penambahan Khitosan Pada Pakan Ikan Bandeng (Chanos chanos) Sebagai Penurun Cita Rasa Lumpur (Geosmine). Embryo, VIII (2): 126132.

Kaligis, Y. E. 2010. Peningkatan Sintasan dan Kinerja Pertumbuhan Udang Vaname (Litopenaeus vannamei) di Media Bersalinitas Rendah. Disertasi. Institut Pertanian Bogor. Bogor. 160 hal.

Kepala Pusat Penyuluhan Kelautan dan Perikanan. 2011. Budidaya Udang Vaname (Litopenaeus vannamei). Jakarta. 52 hal.

Kusriningrum. 2009. Perancangan Percobaan. Fakultas Kedokteran Hewan Universitas Airlangga. Surabaya. Hal. 1.

Meshkini, S., A. A. Tafy, A. Tukmechi and F. F. Pajuh. 2012. Effects of Chitosan on Hematological Parameters and Stress Resistance in Rainbow Trout (Onocorhynchus mykiss). Veterinary Research Forum, III (1): 49-54.

Pujiati, Sarjito dan Suminto. 2013. Pengaruh Penambahan Tepung Cacing Tanah (Lumbricus rubellus) Dalam Pakan Buatan Terhadap Jumlah Total Hemosit dan Aktivitas Fagositosis Udang Vanname (Litopenaeus vannamei). Jurnal Manajemen Akuakultur dan Teknologi, II (1): 66-74.

Putri, F.M., Sarjito dan Suminto. 2013. Pengaruh Penambahan Spirulina sp. Dalam Pakan Buatan Terhadap Jumlah Total Hemosit dan Aktivitas Fagositosis Udang Vaname (Litopenaeus vannamei). Jurnal Fakultas Perikanan dan Ilmu Kelautan Universitas Diponegoro, 1(2): 102112.

Salfira. 1998. Pengaruh Pemberian LPS (Lipopolisakarida) Dari Dinding 
Sel Bakteri Vibrio harveyi Terhadap Gambaran Sistem Kekebalan Non-Spesifik Pada Udang Windu (Penaeus monodon Fabr.). Tesis. Program Pascasarjana. Institut Pertanian Bogor. Bogor. 56 hal.

Subyakto S. 2000. Pengaruh Kadar 1ascorbyl-2-phosphate-magnesium (APM) Pakan Terhadap Kadar Vitamin C Hati, Asam Lemak n-6 dan n-3 dan Rasio Hydroksiprolin/Prolin Tubuh dan Kinerja Pertumbuhan Serta Respon Stres Juvenil Ikan Kerapu Tikus (Cromileples altivelis). Tesis. Program Pascasarjana, Institut Pertanian Bogor. 86 hal.

Sukenda, Y., Tri Anggoro, D., Wahyuningrum dan Rahman. 2007. Penggunaan Kitosan untuk Pengendalian Infeksi Vibrio harveyi pada Udang Putih Litopanaeus vannamei. Jurnal Akuakultur Indonesia, VI (2); 205-209.

Suptijah, P. 2006. Deskriptif Karakteristik Fungsional dan Aplikasi Kitin Kitosan. Prosiding Seminar Nasional Kitin Kitosan. Departemen Teknologi Hasil Perikanan. Institut Pertanian Bogor. Bogor. 11 hal.

Taqwa, F. H. 2008. Pengaruh Penambahan Kalium Pada Masa Adaptasi Penurunan Salinitas dan Waktu Penggantian Pakan Alami Oleh Pakan Buatan Terhadap Performa Pascalarva Udang Vaname (Litopenaeus vannamei). Tesis. Institut Pertanian Bogor. Bogor. 100 hal.

Taqwa, F. H., A. D. Sasanti dan K. Gaffar. 2012. Kelangsungan Hidup, Kerja Osmotik dan Konsumsi Oksigen Pascalarva Udang Galah Selama Penurunan Salinitas Dengan Air Rawa Pengencer Yang Ditambahkan Kalium. Prosiding InSINas. Hal 98-102.

Tayibu, H. 2012. Respon Fisiologi Juvenil Udang Windu, Penaeus monodon Fabricius Pada Bobot dan Densitas Pemeliharaan Yang Berbeda Dalam
Wadah Terkontrol. Disertasi. Program Pascasarjana. Universitas Hasanuddin. Makasar. 179 hal.

Van de Braak, K. 2002. Haemocytic Defence in Black Tiger Shrimp (Penaeus monodon). PhD Thesis. Wageningen University. Wagenigen. The Netherlands. 168 page. 